\title{
A Case of a Laryngocele with Recurrent Infection
}

\author{
Seiichi Nakano ${ }^{1)}$, Hironori Akizuki ${ }^{2)}$, Hidetaka Iwasaki ${ }^{2}$, \\ Satoko Yamashita ${ }^{3)}$, Yoshiyuki Fujii ${ }^{3)}$, Eiji Kondo ${ }^{1)}$, \\ Haruhiko Shizuku ${ }^{4)}$, Koichi Tamura ${ }^{5)}$ and Noriaki Takeda ${ }^{5)}$
}

\begin{abstract}
We report herein on a case of laryngocele with recurrent infection. A 48-year-old male complained of hoarseness and swelling of the left side of his neck. The endoscopic and CT scan examinations demonstrated the combined type of laryngocele that had expanded through the thyrohyoid membrane and had swollen up both medially and laterally in a dumbbell-like shape. To avoid the risk of laryngeal stenosis with the enlarged laryngocele infected by bacteria, in addition to intravenous infusion of an anti-bacterial drug, purulent discharge was drained from the infected laryngocele with a puncture needle. Because infection of the laryngocele was recurrent, it was surgically removed via an external neck approach under general anesthesia without any prophylactic tracheotomy. The laryngocele may be translated from a saccular cyst that had developed after the obstruction of communication between the laryngeal ventricle and the laryngeal saccule.
\end{abstract}

Keywords : laryngocele, saccular cyst, laryngeal ventricle, laryngeal saccule, laryngopyocele

\section{References}

1) Holinger LD, Barnes DR, Smid LJ, et al. : Laryngocele and saccular cysts. Ann Otol Rhinol Laryngol 87: 675-685, 1978.

2) Lindsay JR : Laryngocele ventricularis. Ann Otol Rhinol Laryngol 49: 661-673, 1940.

3）秋田谷直：Laryngocele の自験例と文献的考察. 日気管食道 会報 32: 287-299, 1981 .

4) DeSanto LW : Laryngocele, laryngeal mucocele, large saccules, and laryngeal saccular cysts: a developmental spectrum. Laryngoscope 84: 1291-1296, 1974.

5) Beautyman W, Haidak GL and Taylor M : Laryngopyocele; report of a fatal case. N Engl J Med 260: 1025-1027, 1959.

6) 河野 寿：ラリンゴケーレの 1例. 耳鼻咽喉 51:393-395, 1979.

7）渡辺尚彦, 賀来光寛, 中島 仁, 他 : laryngopyocele の 1 例. 耳鼻咽喉 56: 361-364, 1984.

8）上田良穂, 吉浜博太, 小林恵子, 他: 甲状軟骨の変形を伴っ

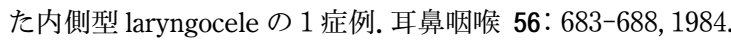

9）田島文司, 皿井靖長, 小林武夫, 他: 甲状軟骨の変形を伴っ た混合型 Laryngocele の 1 症例. 耳鼻・頭頸外科 62：1179-
$1183,1990$.

10）高原 幹, 小林吉史, 林 浩, 他 : Laryngocele の 1 症 例. 喉頭 8: 155-159, 1996.

11）千々和圭一, 草場 隆, 森一功, 他：頸部外切開により 摘出した laryngocele 症例. 日気管食道会報 50：420-424, 1999.

12）宮崎和浩, 石川雅洋, 杉原功一, 他 : laryngocele 症例. 耳 鼻と臨 46: 180-184, 2000.

13) Endo $Y$ : A case of combined laryngocele. Pract Otol (Kyoto) 103: $563-567,2010$.

14）乾 崇樹, 東川雅彦, 牧本一男, 他: 直達鏡下 $\mathrm{CO}_{2}$ レー ザーによるラリンゴケーレの治療経験. 耳鼻・頭頸外科 75 : 862-866, 2003.

15）細川清人：ラリンゴマイクロサージャリー下に囊胞開空術 を行った Laryngocele の 1例. 日気管食道会報 61：388-394, 2010.

16) Wright LD Jr and Maguda TA : Laryngocele: case report and review of the literature. Laryngoscope 74: 396-412, 1964.

17) Micheau C, Luboinski B, Lanchi $P$, et al. : Relationship between laryngoceles and laryngeal carcinomas. Laryngoscope 88: 680-688, 1978.
1) Department of Otolaryngology, NHO Kochi National Hospital

2) Department of Otolaryngology, Tokushima Red Cross Hospital

3) Department of Pathology, Tokushima Red Cross Hospital

4) Department of Otolaryngology, JA Kochi Hospital

5) Department of Otolaryngology, University of Tokushima
Corresponding Author Address : Seiichi Nakano 5571nakano@gmail.com 
18) Pietrantoni L, Felisati D and Finzi A : Laryngocele and laryngeal cancer. Ann Otol Rhinol Laryngol 68: 100-107, 1959.

19) Pak MW, Woo JK and van Hasselt CA : Congenital laryngeal cysts: current approach to management. J Laryngol Otol 110: 854-856, 1996.

20) Civantos FJ and Holinger LD : Laryngoceles and saccular cysts in infants and children. Arch Otolaryngol Head Neck Surg 118: 296-300, 1992.

21) Ward RF, Jones J and Arnold JA : Surgical management of congenital saccular cysts of the larynx. Ann Otol Rhinol Laryngol 104: 707-710, 1995.
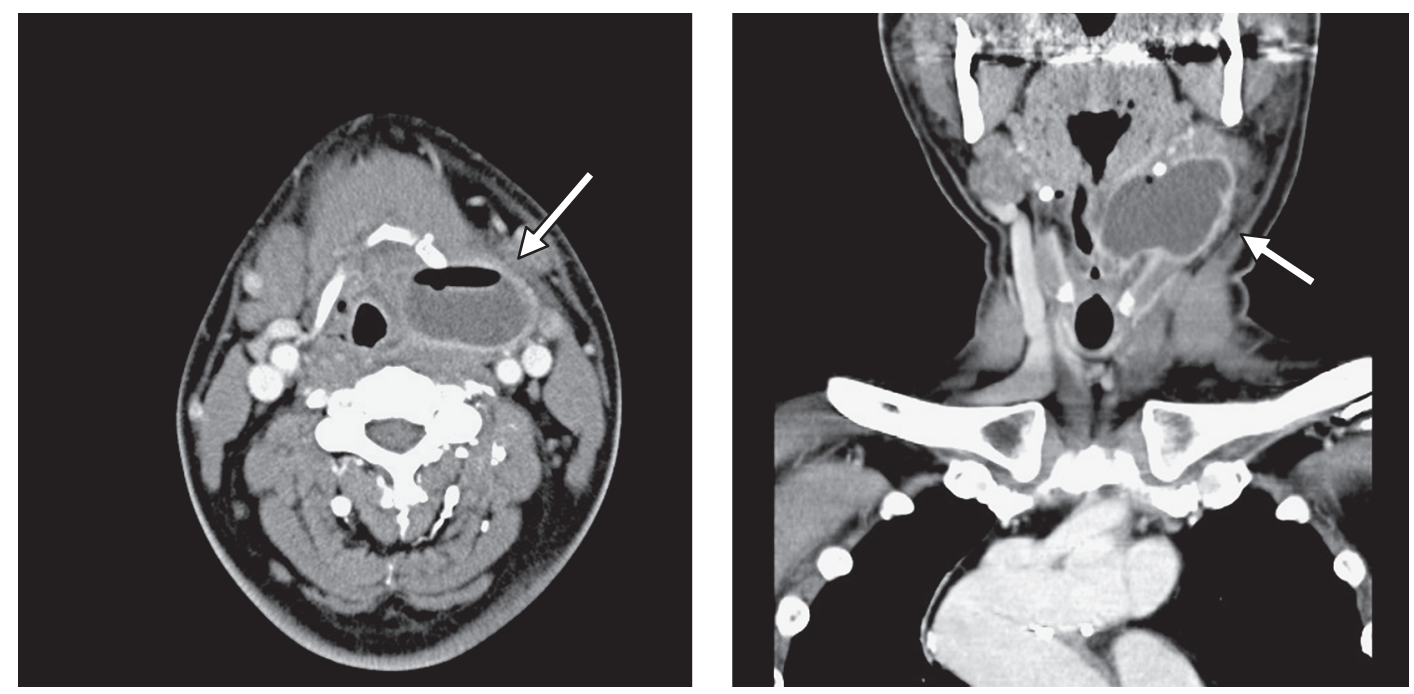

Enhanced computed tomography of the neck at the first visit Computed tomography demonstrates the combined type of laryngocele that had expanded through the thyrohyoid membrane and had swollen up both medially and laterally in a dumbbell-like shape.
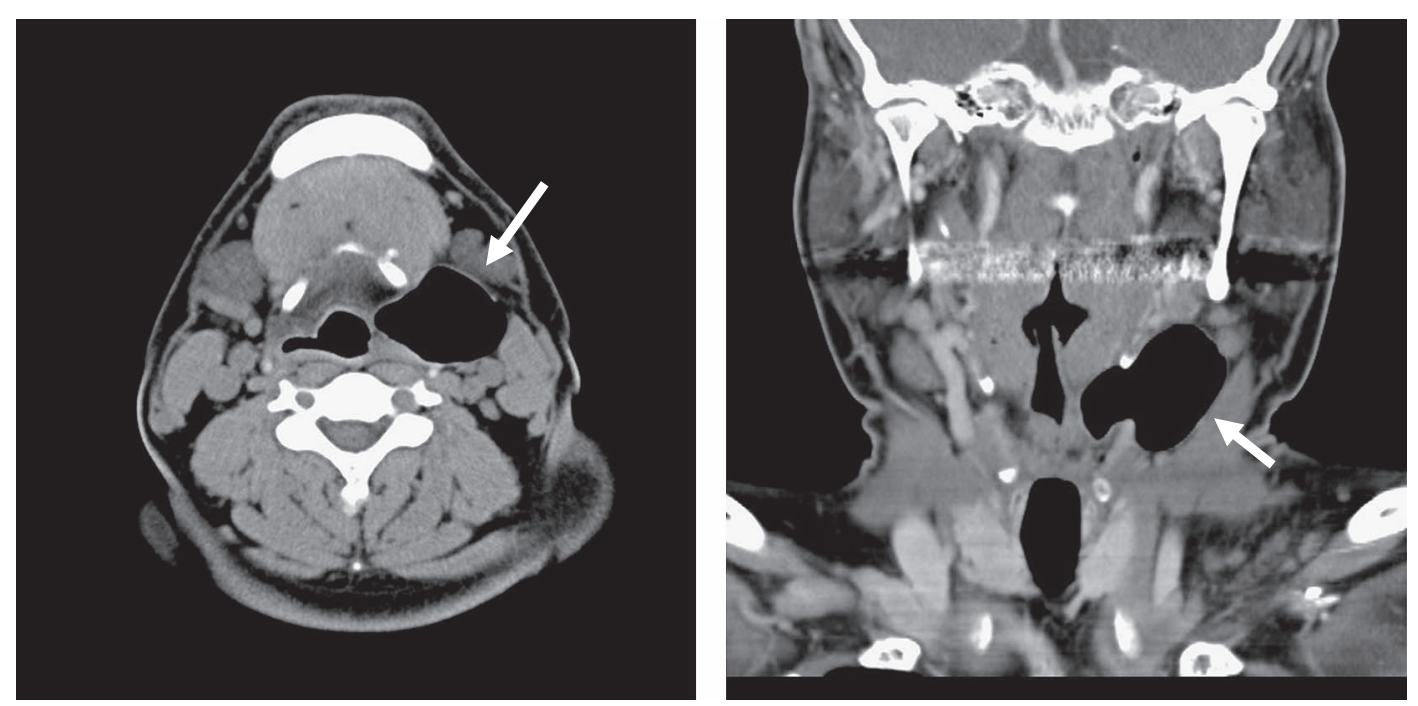

Preoperative computed tomography of the neck

The liquid contents in the laryngocele have disappeared. 